\title{
INTERNATIONAL
}

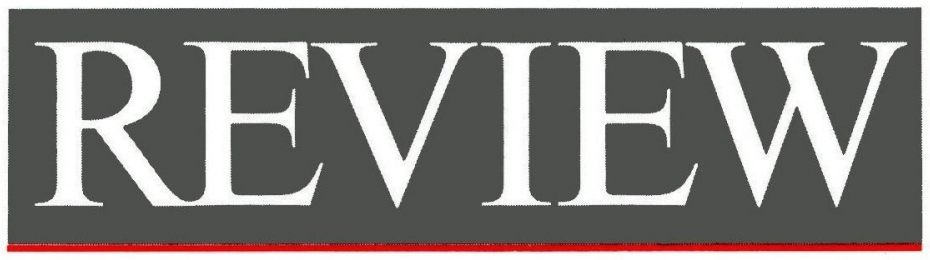

OF THE RED CROSS

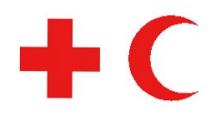

Published every two months by the International Committee of the Red Cross for the International Red Cross and Red Crescent Movement

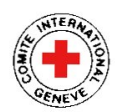




\title{
INTERNATIONAL COMMITTEE OF THE RED CROSS
}

Mr. CORNELIO SOMMARUGA, Doctor of Laws of the University of Zurich. Doctor h.e. $(")$. phl of Fribourg University (Switzerland), Doctor h.c. in International Relations of Minho Dinversity. Braga (Portugal), Doctor h.c. of Medicine of Bologna University (Italy). Doctor h.c. of NiceSophia Antipolis University, Doctor h.c. of Scoul National University (Republic of Koreal. President (member since 1986)

Mr. PIERRE KELLER. Doctor of Philosophy in International Relations (Yalc), banker. Iir' ${ }^{\prime}$ President (1984)

Mr. CLAUDIO CARATSCH, Bachelor of Arts, Vice-President (1990)

Mr. ULRICH GALDENZ MIDDENDORP, Doctor of Medieine, lecturer at the Faculty of Medicine of Zurich University, former head of the surgical department of the Cantonal Hospital. Winterthur (1973)

Mr. MAURICE AUBERT, Doctor of Laws, Barrister, Vice-President from 1984 to 1991 (1979)

Mr. DIETRICH SCHINDLER, Doctor of Laws, Honorary Professor at the University of Zurich (1961. 1973) (1980)

Mrs. RENÉE GUISAN, General Secretary of the international Institul de la lice, head of medico-social institutions in the Canton of Vaud, member of the International Association for Volunteer Fiffort (1986)

Mrs. ANNE PETITPIERRE, Doctor of Laws, Barrister, Professor at the Law Faculty of the University of Geneva (1987)

Mr. PAOLO BERNASCONI, Barrister, LL. L., lecturer in economic criminal tat at the Universities of St. Gallen and Zurich, former Public Prosecutor at Lugano. member of the Swiss Pro Juventute Foundation (1987)

Mrs. LISELOTTE KRAUS-GURNY, Doctor of Laws of the University of \%urich (1988)

Mrs. SUSY BRUSCHWEILER, nurse, Director of the Swiss Red Cross College of Nursing iri Airau (1988)

Mr. JACQUES FORSTER, Doctor of Economics, Prolessor at the Graduate Institute of Developntent Studies in Geneva (1988)

Mr. JACQUES MOREILLON. Bachelor of Laws, Doctor of Political Science. Secretary General of the World Organization of the Scout Movement, former Director General at the ICRC (1988)

Mr. MAX DAETWYLER, graduate in Economics and Social Sciences of the University of Geneva. Scholar in Residence of the International Management Institute (IMI) of Geneva (1989)

Mr. RODOLPHE DE HALLER, M. D., lecturer at the Faculty of Medicine of the University of Geneva, President of the Swiss Association Against Tuberculosis and Lung Direases (1991)

Mr. DANIEL THURER, LL. D., LL. M. (Cambridge), Professor at the University of Zurich (1991)

Mrs. FRANCESCA POMETTA, Bachelor of Arts, former Swiss Ambassador (1991)

Mr. JEAN-FRANÇOIS AUBERT, LL. D., Professor at the University of Neuchatel, former member of the Swiss National Council and Council of States (1993)

Mr. JOSEF FELDMANN, Ph.D., tenured professor at the University of St. Gallen. Corps Commander (Rid.) of the Swiss army (1993)

Mrs. LILIAN UCHTENHAGEN, Doctor of Economics of the University of Basel, former member of the Swiss National Council (1993)

Mr. GEORGES-ANDRE CUENDET, Bachelor of Laws of the University of Geneva, graduate of the Institute of Political Studies of the University of Paris, M.A. from Stanford University (USA). member of the Administrative Council of Cologny, Geneva (1993)

\section{EXECUTIVE BOARD}

\author{
Mr. CORNELIO SOMMARUGA, Presidem \\ Mr. CLAUDIO CARATSCH, permanent Vice-President \\ Mr. JACQUES FORSTER, member of the ICRC \\ Mrs. ANNE PETITPIERRE, member of the $I C R C$ \\ Mr. PETER FUCHS, Director General \\ Mr. JEAN DE COURTEN, Director of Operations \\ Mr. YVES SANDOZ, Director for Principles, Law
}

and Relations with the Movenem 


\section{INTERNATIONAL REVIEW OF THE RED CROSS}

\section{CONTENTS}

MAY-JUNE 1994

No. 300

\section{REPRESSION OF BREACHES OF INTERNATIONAL HUMANITARIAN LAW}

Juan José Quintana: Violations of international humanitarian law and measures of repression: The International Tribunal for the former Yugoslavia

María Teresa Dutli and Cristina Pellandini: The International Committee of the Red Cross and the implementation of a system to repress breaches of international humanitarian law

\section{IMPLEMENTATION OF HUMANITARIAN LAW}

Krister Thelin: Legal advisers to the armed forces - The Swedish experience

\section{IDENTIFICATION}

Gérald C. Cauderay: Means of identification for protected medical transports 


\section{IN THE RED CROSS AND RED CRESCENT WORLD}

\section{Seventy-fifth Anniversary of the founding of the International}

Federation of Red Cross and Red Crescent Societies ............... 279

- Official celebration (Paris, 5 May 1994) .................................... 280

- Address by the President of the ICRC, Mr. Cornelio Sommaruga, at the Ministry of Foreign Affairs

- Address by the President of the Federation, Mr. Mario Villarroel Lander, at the Ministry of Foreign Affairs

Statutory meetings of the Movement (Paris, 3-6 May 1994) .............. 285

Dr. Jean Guillermand: The medical and social vocation of the French Red Cross

Recognition of the Andorra Red Cross ................................................ 296

\section{MISCELLANEOUS}

The Republic of San Marino ratifies the Protocols .......................... 298

Accession to the Protocols by Ethiopia ............................................ 298

Award of the Paul Reuter Prize ..................................................... 299

\section{BOOKS AND REVIEWS}

L'action caritative du Saint-Siège en faveur des prisonniers de guerre (1939-1945) (The Holy See and its charity work in behalf of prisoners of war, 1939-1945) (Léon Papeleux)

Voluntary service - Current status report, volunteer management cycle (Mary Harder)

Nouvel ordre mondial et droits de l'homme - La guerre du Golfe (New' world order and human rights - The Gulf War) (Paul Tavernier, ed.) 